\title{
Editorial \\ Oligometastatic Cancer: Key Concepts and Research Opportunities for 2021 and Beyond
}

\author{
Petr Szturz $^{1}$ (D) and Jan B. Vermorken ${ }^{2,3, *}$ \\ 1 Medical Oncology, Department of Oncology, Lausanne University Hospital (CHUV), \\ 1011 Lausanne, Switzerland; szturz@gmail.com \\ 2 Department of Medical Oncology, Antwerp University Hospital, 2650 Edegem, Belgium \\ 3 Faculty of Medicine and Health Sciences, University of Antwerp, 2610 Antwerp, Belgium \\ * Correspondence: JanB.Vermorken@uza.be; Tel.: +32-3-8214548
}

check for updates

Citation: Szturz, P.; Vermorken, J.B. Oligometastatic Cancer: Key Concepts and Research Opportunities for 2021 and Beyond. Cancers 2021, 13, 2518. https://doi.org/10.3390/ cancers 13112518

Received: 3 May 2021

Accepted: 13 May 2021

Published: 21 May 2021

Publisher's Note: MDPI stays neutral with regard to jurisdictional claims in published maps and institutional affiliations.

Copyright: (c) 2021 by the authors. Licensee MDPI, Basel, Switzerland. This article is an open access article distributed under the terms and conditions of the Creative Commons Attribution (CC BY) license (https:// creativecommons.org/licenses/by/ $4.0 /)$.
Traditionally, clinicians distinguished three forms of cancer outgrowth. Classification in early, locally or locoregionally advanced, and metastatic disease had purposefully reflected patient prognosis and treatment options. More recently, we learned that some molecular features, such as positivity for human papillomavirus (HPV) in oropharyngeal cancer, may partially equalize prognostic differences between these categories, particularly between early and locoregionally advanced stages [1]. There are more examples demonstrating imperfections of simplified models used in clinical practice if not supported by a solid understanding of disease biology. It is therefore intriguing to speculate on molecular mechanisms that can cut out a piece of the metastatic spectrum and set a specific situation in oncology known as oligometastatic cancer. Usually defined by the presence of one to five distant lesions safely treatable with local approaches, it can be considered an intermediate state between a locoregional and typical polymetastatic disease (Figure 1) [2,3]. Mounting evidence has demonstrated that this distinction is based on biological characteristics including genetic determinants (e.g., PBRM1 mutations), epigenetic modifiers (e.g., overexpression of 14q32-encoded miRNAs), and immune response markers (such as $\mathrm{CD}^{+}$ and $\mathrm{CD} 8^{+}$T-cell infiltration) [4].

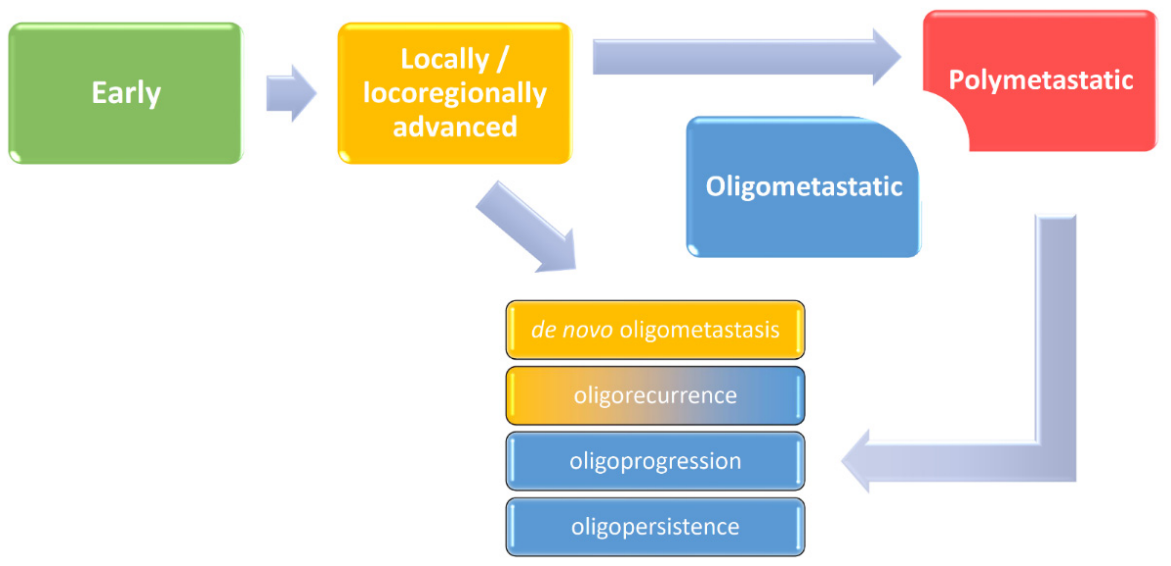

Figure 1. Development of clinically overt malignant disease with a possibility of oligometastatic cancer, as an intermediate state between locoregionally advanced and typical metastatic disease, and its different forms.

The clinical concept of the oligometastatic state has its origins in metastasectomies performed in the 1920s and 1930s. In the following 50 years, complete resection of hepatic metastases from colorectal carcinomas and pulmonary metastases from sarcomas and renal cell cancers emerged as a potentially curative intervention. In the 1990s, stereotactic 
(ablative) body radiotherapy (SABR/SBRT) developed as an alternative to metastasectomy, and around the same time, Hellman and Weichselbaum coined the term "oligometastases". Parallelly, radiofrequency ablation was modified to be applied percutaneously and used to treat liver tumours under radiological guidance. Further methods were also made available in oncology, including cryotherapy, lasers, microwave hyperthermia, high-intensity focused ultrasound, and ethanol injections [5,6]. Subsequently, moving from the period of nosological evolution and therapeutic development, we have entered a new era aiming at reliable prediction and individualization.

Oligometastatic disease has been in the spotlight of researchers, with a markedly growing number of new scientific papers every year (Figure 2) and even penetrating into the latest staging system of the American Joint Committee on Cancer (AJCC) for non-small cell lung cancer [1]. This is not surprising because it has been shown that local ablation of limited metastases can lead to prolonged disease control and eventually cure, such as in some oligometastatic HPV-positive oropharyngeal cancer cases. However, there are more objectives to attain and more indications and scenarios to intervene. Not yet standardized but already adopted by numerous investigators, the current terminology restricts the use of "oligometastasis" to newly diagnosed cases (synchronously with the primary tumour), while the term "oligorecurrence" should be reserved for a metachronous dissemination (> 3-6 months after the primary cancer diagnosis) or to a new manifestation in patients with a history of a prior metastatic disease. In those undergoing anticancer treatment, we may speak of "oligoprogression" if few distant lesions grow or "oligopersistence" if disease control has been achieved (Figure 1) [2,3]. Therefore, local ablation has an important position both as an adjunct to and a replacement of systemic treatment in the palliative setting, which is reinforced by its generally advantageous toxicity profile.

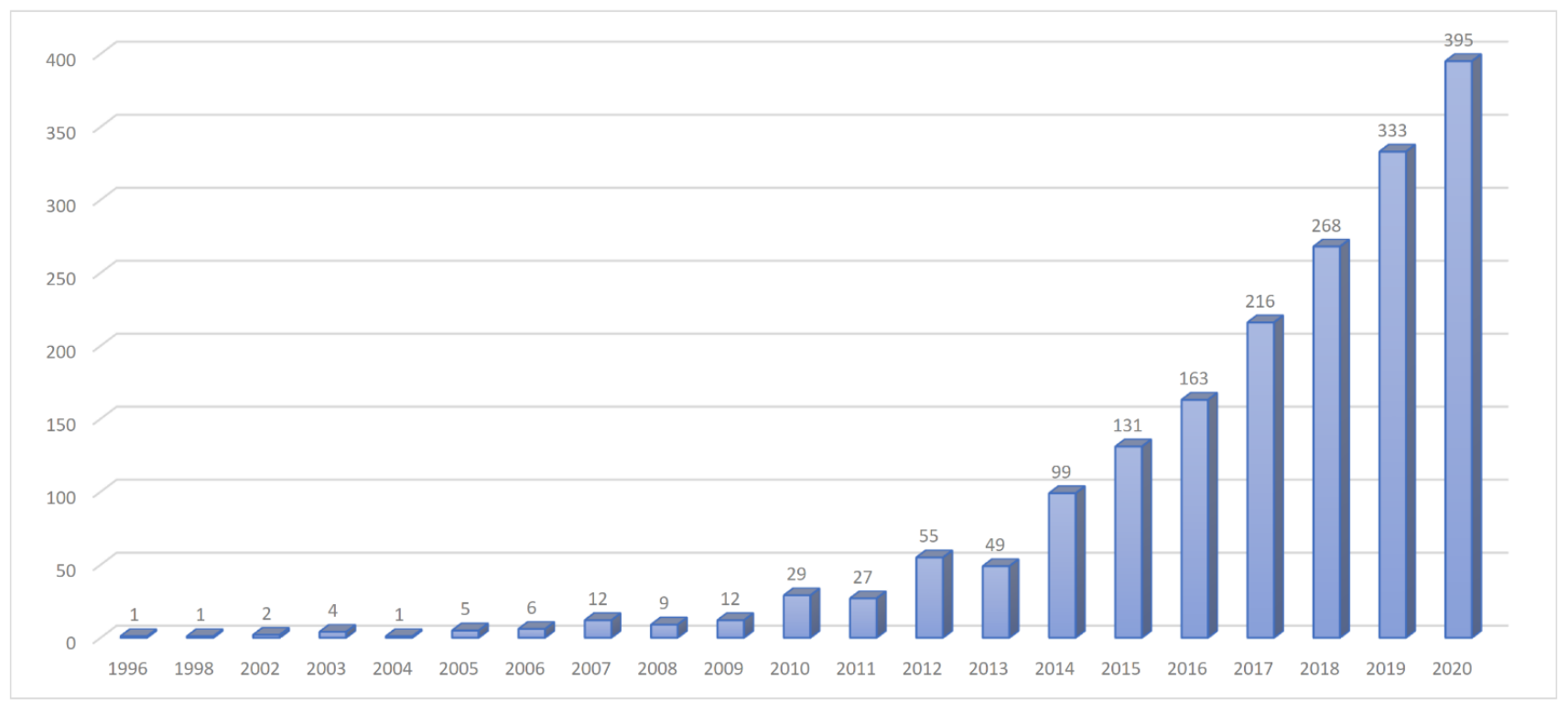

Figure 2. Increasing number of scientific papers on oligometastatic disease per year from 1996 to 2020. Results correspond to the search term "oligometastatic" in the National Library of Medicine on 4 April 2021 (https:/ pubmed.ncbi.nlm.nih.gov).

Compared with a leukaemia-like dissemination of many malignant processes, the encouraging aspect of a spatially limited oligometastatic disease has ignited a steep rise of scientific interest with new research questions and challenges. We have divided them in three main categories, summarized in Table 1 [2-4,7-30]. One of the major drawbacks of the oligometastatic concept is the current perception relying on therapeutic opportunity and cross-sectional imaging rather than intra- and intercellular processes [7]. This can be partially bypassed by refining diagnostic criteria in that we include disease kinetics measures, molecular imaging, and predictive nomograms, but sooner or later a better understanding 
of disease biology will become indispensable for further progress [4,7,10-13]. If we accept the contemporary definition and its shortcomings, the next step is to determine the optimal treatment strategy. The body of existing evidence, especially from phase III trials, is far from satisfactory, and improvements are already needed at the level of study design with respect to clinical endpoints and the choice of modalities $[9,24,29]$. The latter aspect may indeed be crucial not only due to the large range of possible treatment options and indications, but also because of various combinations and sequencing schedules [9,14-18]. It is therefore noteworthy that local ablation should not be used indiscriminately in the oligometastatic setting. The decision making is a multistep process influenced by the technical feasibility of a given procedure and clinical judgement of its relevance based on patient-related and disease-related factors [5]. Moreover, some of the positive randomized trials, including the CLOCC trial investigating radiofrequency ablation and the SABR-COMET trial evaluating stereotactic radiotherapy, were criticised for imbalances between the treatment arms. Further doubts have been raised following the publication of the PulMiCC trial which did not find a benefit of pulmonary metastasectomy over active monitoring in 65 colorectal cancer patients [30].

Despite these controversies and information gaps, local approaches should be praised for their cost-effectiveness, compliance, and low toxicity [21,24,30]. Moreover, oligometastases provide a new and exciting area of scientific opportunities. On the other hand, it is difficult to anticipate their long-term development, as non-invasive modalities may ultimately be preferred, which is also being fuelled by the enormous amount of research invested in modern systemic treatments and accompanying predictive biomarkers. However, technical advances increasing the availability and accessibility of local interventions may revolutionize their use in smaller practices. Already now they are prioritized in certain clinical situations and represent a viable alternative for some patients according to their individual preferences. Local therapies may eventually become inseparable parts of selected anticancer protocols, but will for sure retain their relevance in cases refractory to systemic therapies and in resource-limited countries remaining out of reach of the latest medicines. 
Table 1. An overview of key concepts and research opportunities in oligometastatic cancer.

\begin{tabular}{|c|c|c|c|}
\hline Domain & Issue & Challenges & Progress and Objectives \\
\hline \multirow{4}{*}{ Biology } & \multirow{2}{*}{$\begin{array}{l}\text { Determinants of } \\
\text { oligometastatic phenotype }\end{array}$} & Genetic, epigenetic, and immune factors & $\begin{array}{l}\text { PBRM1 mutations, overexpression of 14q32-encoded miRNAs, CD3+ and CD8+ T-cell } \\
\text { infiltration [4] }\end{array}$ \\
\hline & & $\begin{array}{l}\text { Definition based on disease biology } \\
\text { rather than } \\
\text { therapeutic opportunity }\end{array}$ & $\begin{array}{l}\text { Driver mutations, miRNAs, somatic copy number alterations, intratumour } \\
\text { heterogeneity [7] }\end{array}$ \\
\hline & \multirow{2}{*}{$\begin{array}{c}\text { Modifiers of } \\
\text { oligometastatic phenotype }\end{array}$} & Microenvironment & Granzyme-B+ T-cell infiltration [8] \\
\hline & & Abscopal effect as an in vivo vaccine & Concurrent use of SABR and immunologic agents [9] \\
\hline \multirow{6}{*}{ Workup } & \multirow{4}{*}{$\begin{array}{l}\text { Clinical determinants of } \\
\text { oligometastatic phenotype }\end{array}$} & Tumour burden & Number $(\leq 3-5)$, size $(\leq 5 \mathrm{~cm})$, and localization of lesions ( $\leq 3-5$ organs) $[2,10]$ \\
\hline & & Disease kinetics & $\begin{array}{l}\text { Clinical factors (DFS) and biological factors (miRNAs, intratumour heterogeneity, } \\
\text { somatic copy-number alterations) [10] }\end{array}$ \\
\hline & & Disease subtypes & $\begin{array}{l}\text { Synchronous / metachronous, repeat / induced, oligometastasis, oligorecurrence, } \\
\text { oligoprogression, oligopersistence [3] }\end{array}$ \\
\hline & & Prognostic factors & $\begin{array}{l}\text { Nomograms (e.g., the Metabank score for SABR), DFS, tumour markers, baseline } \\
\text { interleukin } 1 \alpha[7,11,12]\end{array}$ \\
\hline & Molecular imaging & New PET tracers & PSMA, Her-2, ${ }^{68}$ Ga-FAPI, PD-L1 [10,13] \\
\hline & Liquid biopsy & Posttreatment follow-up & ctDNA burden, oligoclonal expansion [12] \\
\hline
\end{tabular}


Table 1. Cont.

\begin{tabular}{|c|c|c|c|}
\hline Domain & Issue & Challenges & Progress and Objectives \\
\hline \multirow{22}{*}{ Treatment } & \multirow{4}{*}{ Optimization } & Combinations with systemic therapy & Immune checkpoint inhibitors $[9,14]$ \\
\hline & & Consolidation with local ablation & $\begin{array}{l}\text { Oligometastatic disease after first-line systemic treatment (induced } \\
\text { oligopersistence) [15] }\end{array}$ \\
\hline & & $\begin{array}{l}\text { Radical treatment of the primary tumour in } \\
\text { the setting of synchronous oligometastases }\end{array}$ & Radiotherapy in nasopharyngeal cancer, surgery in non-small cell lung cancer $[16,17]$ \\
\hline & & Treatment sequencing & Systemic treatment before or after local ablation [18] \\
\hline & \multirow{2}{*}{ Innovation } & $\begin{array}{l}\text { Reversal of metastatic to } \\
\text { oligometastatic phenotype }\end{array}$ & Epigenetic modifiers [10] \\
\hline & & New technologies & $\begin{array}{l}\text { Magnetic resonance-guided radiotherapy, single-cell sequencing, Holmium-166 } \\
\text { microsphere selective radioembolization }[9,19,20]\end{array}$ \\
\hline & \multirow{2}{*}{$\begin{array}{c}\text { Adaptation } \\
\text { (e.g., pandemic scenario) }\end{array}$} & Rationalization of fractionation schedules & Ultra-high single-dose radiotherapy (24 Gy) [21] \\
\hline & & Bridging therapy & Radical radiotherapy to delay curative surgery [22] \\
\hline & \multirow{3}{*}{ Individualization } & Predictive factors & Baseline immune phenotype and tumour mutation status [13] \\
\hline & & Biological age & SABR in unfit elderly patients [23] \\
\hline & & Choice of a local ablation tool & Patient-, disease-, resource-, and experience-related factors $[9,24]$ \\
\hline & \multirow{3}{*}{ Expansion } & New indications & e.g., pancreatic cancer [25] \\
\hline & & Paediatric patients & Sarcomas (e.g., rhabdomyosarcoma) [26] \\
\hline & & $\begin{array}{l}\text { Upfront local ablation in } \\
\text { polymetastatic disease }\end{array}$ & $\begin{array}{l}\text { Cytoreduction, elimination of immunotherapy- and TKI-resistant clones, enhancement } \\
\text { of tumour antigen presentation and immunogenicity [18] }\end{array}$ \\
\hline & De-escalation & In combination with immunotherapy & Worse local control with low doses of SABR (<60 Gy) [14] \\
\hline & Timing & $\begin{array}{l}\text { Synchronous vs. metachronous } \\
\text { oligometastases }\end{array}$ & Better outcomes in the metachronous setting [11] \\
\hline & \multirow{4}{*}{ Benefits and drawbacks } & Rare adverse events & Thermal ablation and cryoablation of liver metastases, embolization [24] \\
\hline & & Patient reported outcomes & Pain response and quality of life [27] \\
\hline & & Cost-effectiveness & SABR more cost-effective than systemic therapy [28] \\
\hline & & Resource-limited countries & SABR, particularly single-dose radiotherapy $[21,28]$ \\
\hline & \multirow{2}{*}{ Clinical trial design } & New endpoints adjusted to local ablation & $\begin{array}{l}\text { Corrected DFS, Time to New Systemic Therapy, WideSpread Progression-Free } \\
\text { Survival [29] }\end{array}$ \\
\hline & & Addressing ambiguous results & Local ablation of pulmonary metastases in colorectal cancer [30] \\
\hline
\end{tabular}

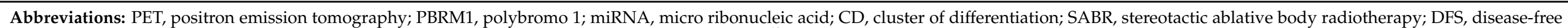

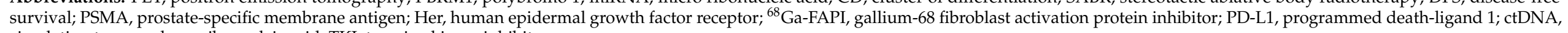
circulating tumour deoxyribonucleic acid; TKI, tyrosine kinase inhibitor. 
Funding: This research received no external funding.

Conflicts of Interest: P.S.: has had in the last three years or has advisory relationships with: MerckSerono, Servier, and BMS. J.B.V.: has had in the last three years or has consulting/advisory relationships with: Immunomedics, Innate Pharma, Merck-Serono, Merck Sharp \& Dome Corp, PCI Biotech, Synthon Biopharmaceuticals, Debiopharm, Cue Biopharma, and WntResearch and received lecture fees from Merck-Serono, MSD, and BMS.

\section{References}

1. Amin, M.B.; Edge, S.; Greene, F.; Byrd, D.R.; Brookland, R.K.; Washington, M.K.; Gershenwald, J.E.; Compton, C.C.; Hess, K.R.; Sullivan, D.C.; et al. (Eds.) AJCC Cancer Staging Manual, 8th ed.; Springer International Publishing: Cham, Switzerland, 2017.

2. $\quad$ Lievens, Y.; Guckenberger, M.; Gomez, D.; Hoyer, M.; Iyengar, P.; Kindts, I.; Méndez Romero, A.; Nevens, D.; Palma, D.; Park, C.; et al. Defining oligometastatic disease from a radiation oncology perspective: An ESTRO-ASTRO consensus document. Radiother. Oncol. 2020, 148, 157-166. [CrossRef] [PubMed]

3. Guckenberger, M.; Lievens, Y.; Bouma, A.B.; Collette, L.; Dekker, A.; deSouza, N.M.; Dingemans, A.C.; Fournier, B.; Hurkmans, C.; Lecouvet, F.E.; et al. Characterisation and classification of oligometastatic disease: A European Society for Radiotherapy and Oncology and European Organisation for Research and Treatment of Cancer consensus recommendation. Lancet Oncol. 2020, 21, e18-e28. [CrossRef]

4. Gutiontov, S.I.; Pitroda, S.P.; Weichselbaum, R.R. Oligometastasis: Past, Present, Future. Int. J. Radiat. Oncol. Biol. Phys. 2020, 108, 530-538. [CrossRef] [PubMed]

5. Szturz, P.; Nevens, D.; Vermorken, J.B. Oligometastatic Disease Management: Finding the Sweet Spot. Front. Oncol 2020, 10, 617793. [CrossRef] [PubMed]

6. McGahan, J.P.; van Raalte, V.A. History of Ablation. In Tumor Ablation, 1st ed.; van Sonnenberg, E., McMullen, W.N., Solbiati, L., Livraghi, T., Müeller, P.R., Silverman, S.G., Eds.; Springer: New York, NY, USA, 2005; pp. 3-16.

7. Foster, C.C.; Pitroda, S.P.; Weichselbaum, R.R. Definition, Biology, and History of Oligometastatic and Oligoprogressive Disease. Cancer J. 2020, 26, 96-99. [CrossRef] [PubMed]

8. Ottaiano, A.; Caraglia, M.; Di Mauro, A.; Botti, G.; Lombardi, A.; Galon, J.; Luce, A.; D’Amore, L.; Perri, F.; Santorsola, M.; et al. Evolution of Mutational Landscape and Tumor Immune-Microenvironment in Liver Oligo-Metastatic Colorectal Cancer. Cancers 2020, 12, 3073. [CrossRef]

9. Murali, N.; Ludwig, J.M.; Nezami, N.; Kim, H.S. Oligometastatic Disease and Interventional Oncology: Rationale and Research Directions. Cancer J. 2020, 26, 166-173. [CrossRef]

10. Gutiontov, S.I.; Pitroda, S.P.; Tran, P.T.; Weichselbaum, R.R. (Oligo)metastasis as a Spectrum of Disease. Cancer Res. 2021, 20, 3337. [CrossRef]

11. Van den Begin, R.; Engels, B.; Collen, C.; de Vin, T.; Defauw, A.; Dubaere, E.; Barbé, K.; De Ridder, M. The METABANK score: A clinical tool to predict survival after stereotactic radiotherapy for oligometastatic disease. Radiother. Oncol. 2019, 133, 113-119. [CrossRef] [PubMed]

12. Tang, C.; Lee, W.C.; Reuben, A.; Chang, L.; Tran, H.; Little, L.; Gumbs, C.; Wargo, J.; Futreal, A.; Liao, Z.; et al. Immune and Circulating Tumor DNA Profiling After Radiation Treatment for Oligometastatic Non-Small Cell Lung Cancer: Translational Correlatives from a Mature Randomized Phase II Trial. Int. J. Radiat. Oncol. Biol. Phys. 2020, 106, 349-357. [CrossRef] [PubMed]

13. Phillips, R.; Shi, W.Y.; Deek, M.; Radwan, N.; Lim, S.J.; Antonarakis, E.S.; Rowe, S.P.; Ross, A.E.; Gorin, M.A.; Deville, C.; et al. Outcomes of Observation vs Stereotactic Ablative Radiation for Oligometastatic Prostate Cancer: The ORIOLE Phase 2 Randomized Clinical Trial. JAMA Oncol. 2020, 6, 650-659. [CrossRef]

14. Kroeze, S.G.C.; Fritz, C.; Schaule, J.; Siva, S.; Kahl, K.H.; Sundahl, N.; Blanck, O.; Kaul, D.; Adebahr, S.; Verhoeff, J.J.C.; et al. Stereotactic radiotherapy combined with immunotherapy or targeted therapy for metastatic renal cell carcinoma. BJU Int. 2020, 15, 284. [CrossRef]

15. Gomez, D.R.; Blumenschein, G.R., Jr.; Lee, J.J.; Hernandez, M.; Ye, R.; Camidge, D.R.; Doebele, R.C.; Skoulidis, F.; Gaspar, L.E.; Gibbons, D.L.; et al. Local consolidative therapy versus maintenance therapy or observation for patients with oligometastatic non-small-cell lung cancer without progression after first-line systemic therapy: A multicentre, randomised, controlled, phase 2 study. Lancet Oncol. 2016, 17, 1672-1682. [CrossRef]

16. Shuang, H.; Feng, J.; Caineng, C.; Qifeng, J.; Tin, J.; Yuanyuan, C.; Xiaozhong, C. The value of radical radiotherapy in the primary tumor of newly diagnosed oligo-metastatic nasopharyngeal carcinoma patients. Clin. Transl. Oncol. 2019, 21, 213-219. [CrossRef] [PubMed]

17. Jones, G.D.; Lengel, H.B.; Hsu, M.; Tan, K.S.; Caso, R.; Ghanie, A.; Connolly, J.G.; Bains, M.S.; Rusch, V.W.; Huang, J.; et al. Management of Synchronous Extrathoracic Oligometastatic Non-Small Cell Lung Cancer. Cancers 2021, 13, 1893. [CrossRef]

18. Foster, C.C.; Pitroda, S.P.; Weichselbaum, R.R. Beyond Palliation: The Rationale for Metastasis-Directed Therapy for Metastatic Non-Small Cell Lung Cancer. J. Thorac. Oncol. 2019, 14, 1510-1512. [CrossRef]

19. Corradini, S.; Alongi, F.; Andratschke, N.; Belka, C.; Boldrini, L.; Cellini, F.; Debus, J.; Guckenberger, M.; Hörner-Rieber, J.; Lagerwaard, F.J.; et al. MR-guidance in clinical reality: Current treatment challenges and future perspectives. Radiat. Oncol. 2019, 14, 92. [CrossRef] 
20. Reinders, M.T.M.; Smits, M.L.J.; van Roekel, C.; Braat, A.J.A.T. Holmium-166 Microsphere Radioembolization of Hepatic Malignancies. Semin. Nucl. Med. 2019, 49, 237-243. [CrossRef] [PubMed]

21. Zelefsky, M.J.; Yamada, Y.; Greco, C.; Lis, E.; Schöder, H.; Lobaugh, S.; Zhang, Z.; Braunstein, S.; Bilsky, M.H.; Powell, S.N.; et al. Phase 3 Multi-Center, Prospective, Randomized Trial Comparing Single-Dose 24 Gy Radiation Therapy to a 3-Fraction SBRT Regimen in the Treatment of Oligometastatic Cancer. Int. J. Radiat. Oncol. Biol. Phys. 2021, 21, S0360-S3016.

22. Kidane, B.; Spicer, J.; Kim, J.O.; Fiset, P.O.; Abdulkarim, B.; Malthaner, R.; Palma, D. SABR-BRIDGE: Stereotactic ABlative Radiotherapy Before Resection to AvoId Delay for Early-Stage LunG Cancer or OligomEts During the COVID-19 Pandemic. Front. Oncol. 2020, 10, 580189. [CrossRef] [PubMed]

23. Lancia, A.; Ingrosso, G.; Carosi, A.; Bottero, M.; Cancelli, A.; Turturici, I.; Ponti, E.; Santoni, R. Oligometastatic cancer in elderly patients: The "blitzkrieg" radiotherapy approach: SBRT in oligometastatic elderly patients. Aging Clin. Exp. Res. 2019, 31, 109-114. [CrossRef] [PubMed]

24. Winkelmann, M.T.; Clasen, S.; Pereira, P.L.; Hoffmann, R. Local treatment of oligometastatic disease: Current role. Br. J. Radiol. 2019, 92, 20180835. [CrossRef]

25. Damanakis, A.I.; Ostertag, L.; Waldschmidt, D.; Kütting, F.; Quaas, A.; Plum, P.; Bruns, C.J.; Gebauer, F.; Popp, F. Proposal for a definition of "Oligometastatic disease in pancreatic cancer". BMC Cancer 2019, 19, 1261. [CrossRef]

26. Smile, T.D.; Parsai, S.; Pflederer, T.M.; Murphy, E.S. Treatment paradigms for oligometastatic pediatric cancers: A narrative review with a focus on radiotherapy approaches. Ann. Palliat. Med. 2020, 9, 44. [CrossRef] [PubMed]

27. van de Ven, S.; van den Bongard, D.; Pielkenrood, B.; Kasperts, N.; Eppinga, W.; Peters, M.; Verkooijen, H.; van der Velden, J. Patient-Reported Outcomes of Oligometastatic Patients After Conventional or Stereotactic Radiation Therapy to Bone Metastases: An Analysis of the PRESENT Cohort. Int. J. Radiat. Oncol. Biol. Phys. 2020, 107, 39-47. [CrossRef] [PubMed]

28. Qu, X.M.; Chen, Y.; Zaric, G.S.; Senan, S.; Olson, R.A.; Harrow, S.; John-Baptiste, A.; Gaede, S.; Mulroy, L.A.; Schellenberg, D.; et al. Is SABR Cost-Effective in Oligometastatic Cancer? An Economic Analysis of the SABR-COMET Randomized Trial. Int. J. Radiat. Oncol. Biol. Phys. 2021, 109, 1176-1184. [CrossRef] [PubMed]

29. Loi, M.; Alifano, M.; Scorsetti, M.; Nuyttens, J.J.; Livi, L. Judging a Fish by Its Ability to Climb a Tree? A Call for Novel Endpoints in the Appraisal of Ablative Local Treatments of Oligometastatic Cancer. Oncologist 2021, 13, 747. [CrossRef]

30. Macbeth, F.; Treasure, T. Local treatment of 'Oligometastases': Wishful thinking is not supported by available evidence. Clin. Oncol. 2020, 32, 409. [CrossRef] [PubMed] 